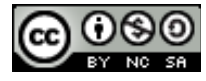

https://doi.org/10.31743/abmk.13003

KS. JAROSŁAW R. MARCZEWSKI* - LUBLIN

\title{
ZBIORY FOTOGRAFICZNE W ARCHIWUM ARCHIDIECEZJALNYM LUBELSKIM
}

\begin{abstract}
Streszczenie
Archiwum Archidiecezjalne Lubelskie przechowuje zbiór ok. 11 tys. fotografii pochodzących z XIX, XX i XXI stulecia. Zbiór ten jest na etapie porządkowania archiwalnego. Nie ma on jeszcze właściwego inwentarza. Na potrzeby wewnętrzne istnieją tylko odpowiednie spisy robocze. Zbiór podzielony jest w porządku akcesji na albumy, kroniki, teczki, koperty i pudła archiwalne. Znacząca część fotografii wchodzi w skład akt personalnych i parafialnych. Zdjęcia są tylko w niewielkim stopniu zdigitalizowane. Ich cyfrowe kopie tworzy się w sposób niesystematyczny, głównie z przeznaczeniem na bieżące wystawy i przygotowywane publikacje. Zbiór fotograficzny cieszy się wzrastającym zainteresowaniem, dlatego pomimo stanu opracowania i przechowywania jest udostępniany. Zawiera on ciekawe obiekty, np. obszerną kolekcję zdjęć zgromadzonych na potrzeby prowadzonych procesów beatyfikacyjnych. Słowa kluczowe: fotografie; digitalizacja; Archiwum Archidiecezjalne Lubelskie; Archidiecezja Lubelska
\end{abstract}

$* * * * *$

Archiwum Archidiecezjalne Lubelskie dysponuje zbiorem fotografii w swoim zasobie archiwalnym. Jak dotąd jednak nie była podejmowana refleksja nad jego stanem liczbowym, stopniem uporządkowania czy zdigitalizowania. Celem niniejszego artykułu, mającego z założenia charakter informatywny, pozostaje rozpoznanie i upublicznienie tych podstawowych faktów. W przyszłości pozwoli to na ich zestawienie $\mathrm{z}$ wiadomościami dotyczącymi tej samej problematyki w innych kościelnych instytucjach archiwalnych, wyciągnięcie odpowiednich wniosków praktycznych i ich metodyczną implementację.

* Ks. Jarosław R. Marczewski - dr hab. historii Kościoła, Instytut Nauk Teologicznych, Katolicki Uniwersytet Lubelski Jana Pawła II

e-mail: jaroslaw.marczewski@kul.pl

https://orcid.org/0000-0002-7021-6806 


\section{Organizacja i zasób archiwum w zarysie}

Archiwum Archidiecezjalne Lubelskie mieści się przy ul. Prymasa Stefana Wyszyńskiego 2, w budynkach zespołu Kurii Metropolitalnej w Lublinie. Od 2012 r. funkcjonuje ono na podstawie odnowionego statutu i regulaminu archiwalnego. W instytucji zatrudnionych jest 6 osób, z których 4 pełnią obowiązki archiwistów i 2 konserwatorów materiałów archiwalnych. Archiwum dysponuje $86 \mathrm{~m}^{2}$ powierzchni biurowej i $181 \mathrm{~m}^{2}$ powierzchni magazynowej. Składa się z 2 czytelni naukowych (jedna służy osobom korzystającym ze zbiorów, druga została częściowo zaadaptowana na potrzeby digitalizacji w ramach projektów realizowanych przez Wydział Administracyjno-Gospodarczy Kurii Metropolitalnej w Lublinie), 6 pomieszczeń magazynowych, gabinetu dyrektora, 2 pokoi archiwistów, pomieszczenia pomocniczego służącego do obsługi korzystających, pomieszczenia służącego do porządkowania zasobu, pomieszczenia socjalnego i pracowni konserwatorskiej. Pomieszczenia magazynowe wyposażone są w metalowe regały jezdne. Zbiory archiwum liczą 928 m.b. Archiwum dysponuje także księgozbiorem podręcznym, na który składają się pozycje książkowe związane tematycznie z dziejami kościelnymi Lubelszczyzny i Chełmszczyzny, jak również periodyki diecezjalne. Księgozbiór podręczny liczy 1947 woluminów ${ }^{1}$.

Archiwum pozostaje codziennie do dyspozycji osóbzainteresowanych zasobem archiwalnym w celach naukowych, dydaktycznych i hobbystycznych. Przykładowo, w całym 2019 r., a więc przed epidemią koronawirusa i wprowadzeniem sanitarnych obostrzeń, odbyło się 187 odwiedzin. Udostępniono w tym czasie 414 j.a. ${ }^{2}$ W 2020 r., w którym nastąpiło długotrwałe zamknięcie archiwum dla osób korzystających, a następnie zastosowanie koniecznego reżimu bezpieczeństwa, przyjęto 43 osoby i udostępniono 157 j.a. ${ }^{3}$ Do dyspozycji osób zainteresowanych archiwaliami pozostaje strona internetowa placówki. Przez cały 2020 r. miała ona 8690 odsłon, dokonanych przez 1690 użytkowników, co stanowi rząd wielkości porównywalny także z poprzednimi latami ${ }^{4}$.

Obecnie dostępne są dla zainteresowanych materiały archiwalne obejmujące okres do końca II wojny światowej. Materiały te mają wydany drukiem inwentarz $^{5}$. Opracowaniu, z zamiarem udostępnienia ich w najbliższym czasie, podlegają aktualnie archiwalia do $1982 \mathrm{r}$.

Współczesne Archiwum Archidicezji Lubelskiej jest spadkobiercą ukształtowanych w różnym stopniu instytucji archiwalnych, funkcjonujących $\mathrm{w}$ ramach podmiotów kościelnych zajmujących w okresie kilku stuleci przestrzeń rozciągającą się na wschód od środkowego biegu Wisły. Wśród tych struktur należy wy-

1 J.R. Marczewski, Archiwum Archidiecezjalne Lubelskie. Dzieje, zasób, inwentarz, Lublin 2015, s. 39-49; Archiwum Archidiecezjalne Lubelskie (dalej: AAL), bez sygn., Sprawozdanie z działalności Archiwum Archidiecezjalnego Lubelskiego za rok 2020, s. 1-12.

${ }^{2}$ AAL, bez sygn., Sprawozdanie z działalności Archiwum Archidiecezjalnego Lubelskiego za rok 2019, s. 6.

${ }^{3}$ AAL, bez sygn., Sprawozdanie z działalności Archiwum Archidiecezjalnego Lubelskiego za rok 2020 , s. 7.

${ }^{4}$ https://analytics.google.com (dostęp: 24.07.2021).

${ }^{5}$ Marczewski, Archiwum Archidiecezjalne Lubelskie, s. 57-600. 
różnić foralny archidiakonat i takiż oficjalat lubelski, lubelską kapitułę kolegiacką, chełmskie biskupstwo obrządku łacińskiego, chełmski konsystorz generalny w Krasnymstawie, chełmską kapitułę katedralną, biskupstwo lubelskie, generalny konsystorz lubelski, diecezjalną kurię lubelską i lubelską kapitułę katedralną. Aktotwórcza działalność tych instytucji znajduje swoje dokumentacyjne odzwierciedlenie we współczesnym zasobie miejscowego archiwum, na które składają się zasadniczo dwie grupy akt. Pierwsza to akta Konsystorza Generalnego Diecezji Lubelskiej oraz akta Kurii Biskupiej (potem Metropolitalnej) w Lublinie. W tej części zasobu - oprócz wymienionych zespołów lubelskiego konsystorza i kurii - znajdują się dawne zespoły akt biskupów chełmskich, konsystorzy diecezji chełmskiej oraz konsystorza lubelskiego z czasów przynależności do diecezji krakowskiej. Druga grupa to akta Kapituły Katedralnej Lubelskiej: dawne zespoły katedralnej kapituły chełmskiej, dawnej lubelskiej kapituły kolegiackiej i wreszcie późniejsze wytwory lubelskiej kapituły katedralnej. W archiwum przechowywane są także duplikaty ksiąg metrykalnych z poszczególnych parafii archidiecezji lubelskiej od $1946 \mathrm{r}$.

Archiwum Archidiecezjalne Lubelskie, zgodnie ze swoim powołaniem, na bieżąco przejmuje wytwory aktotwórczej działalności urzędu arcybiskupiego, poszczególnych agend kurialnych oraz wspomniane duplikaty akt metrykalnych z parafii archidiecezji lubelskiej. W zasobie placówki znajduje się także dokumentacja nieaktowa $\mathrm{w}$ postaci fotografii - zarówno skolekcjonowanych, jak i rozproszonych.

\section{Proweniencja i stan liczebny zbiorów fotograficznych}

Najstarsze spośród fotografii przechowywanych w Archiwum Archidiecezjalnym Lubelskim pochodzą z ostatnich dekad XIX wieku. Można przypuszczać, że niektóre z nich trafiły do archiwalnego zasobu z końcem tego właśnie stulecia. Niemniej jednak w większej liczbie zaczęto je gromadzić z pewnością dopiero $\mathrm{w}$ XX wieku, co było naturalnym procesem związanym $\mathrm{z}$ rozwojem sztuki fotograficznej i odkrywaniem jej dokumentacyjnego charakteru.

Proweniencja przechowywanych $\mathrm{w}$ archiwum fotografii - jako dokumentacji nieaktowej - jest zróżnicowana. Można ją prześledzić w zależności od tego, czy zdjęcia stanowią część innych jednostek archiwalnych, czy też mają charakter samoistny. Zgodnie z usytuowaniem archiwum w strukturze centralnych urzędów archidiecezjalnych fotografie trafiają do niego wraz z dokumentami kancelarii kurialnej (fotografie kapłańskie w aktach personalnych, fotografie infrastruktury kościelnej w aktach parafialnych). Ponadto do instytucji spływają dokumenty kurialnego Wydziału Duszpasterstwa (fotografie z wydarzeń diecezjalnych związanych z profilem agendy), kurialnego Wydziału ds. Wychowania Katolickiego (fotografie z wydarzeń diecezjalnych związanych z profilem agendy, fotografie studentów i absolwentów w aktach personalnych Kolegium Teologicznego Archidiecezji Lubelskiej, działającego w latach 1993-1999), Archidiecezjalnej Komisji Organistowskiej (fotografie osób i obiektów związanych z profilem agendy). Zdjęcia te stanowią dokumentację działalności kościelnej na wybranych odcinkach życia lokalnego Kościoła. Ponadto w archiwum przechowywane są fotografie pozyska- 
ne w drodze darowizny lub spadku po zmarłych księżach i biskupach, stanowiące dokumentację ich osobistego życia i posługi.

Zbiory fotograficzne w Archiwum Archidiecezjalnym Lubelskim liczą ok. 11000 zdjęć. Na wskazaną ogólną liczbę składają się 2684 zdjęcia zgromadzone w 106 albumach, prezentujących wizytacje biskupie, postaci kapłańskie i ich środowisko rodzinne, wydarzenia o charakterze ogólnodiecezjalnym, czynności biskupie. Dla przykładu warto wspomnieć o albumach ilustrujących nawiedzenie figury Matki Bożej Fatimskiej w parafii pw. św. Józefa w Kraśniku w dniach 20-21 lutego 1996 r. (35 zdjęć), koronację figury Matki Bożej Kębelskiej w Wąwolnicy 10 września 1978 r. (90 zdjęć), koronację cudownego obrazu Matki Bożej Różańcowej w Janowie Lubelskim 8 września 1985 r. (60 zdjęć), IV Sesję Plenarną II Synodu Diecezji Lubelskiej 1 czerwca 1985 r. (54 zdjęcia).

Kolejnych 529 fotografii przechowywanych jest w wydzielonych 183 kopertach. Również w tym wypadku mamy do czynienia ze zdjęciami z wydarzeń kościelnych lub dokumentującymi stan budownictwa sakralnego $\mathrm{w}$ archidiecezji.

W wydzielonych 40 teczkach znajduje się kolejnych 298 fotografii. Są to zdjęcia osób kościelnych, chórów parafialnych, organów muzycznych, świątyń i wydarzeń kościelnych.

W 5 pudłach archiwizacyjnych zgromadzono 5194 fotografie. Dotyczą one posługi bp. Piotra Kałwy (813 zdjęć), jak również peregrynacji obrazu Matki Bożej Częstochowskiej do 73 parafii archidiecezji w 2005 r. (4381 zdjęć).

W 11 kronikach 275 fotografii stanowi materiał ilustracyjny różnorodnych okazji życia kościelnego w archidiecezji. Warto wymienić gwoli egzemplifikacji Kronikę nawiedzenia figury Matki Bożej Fatimskiej w Łęcznej 24 lutego 1996 r. (40 zdjęć), Kronikę nawiedzenia figury Matki Bożej Fatimskiej w parafii pw. Wniebowzięcia Najświętszej Maryi Panny w Kraśniku 21 lutego 1996 r. (49 zdjęć), Kroniki z wczasorekolekcji dla osób niepełnosprawnych w Dąbrowicy (100 zdjęć), Kronikę peregrynacji obrazu Matki Bożej Częstochowskiej w Zamościu w $1971 \mathrm{r}$. (46 zdjęć), Kronikę obchodów milenium w Lublinie w 1966 r. (40 zdjęć).

Ciekawostką pozostają przechowywane w archiwum 2 tablice kapituły katedralnej lubelskiej z pierwszej połowy XX wieku i 4 tablice pamiątkowe alumnów seminarium duchownego z okresu międzywojennego. Zdjęcia stanowiące ich integralną część to 212 sztuk.

Znacząca część zbioru fotografii wchodzi w skład akt personalnych i parafialnych. Warto zwrócić uwagę, że zdjęcia kapłanów w ich aktach personalnych występowały zupełnie sporadycznie w XIX i pierwszej połowie XX stulecia. Dopiero od połowy lat 70. XX wieku wprowadzono karty podsumowujące życiową drogę posługi kapłańskiej i włączano je do akt wraz ze zdjęciem identyfikacyjnym księdza. Inicjatywa ta, pozytywnie owocująca gromadzeniem materiału fotograficznego w aktach personalnych, wyszła od ówczesnego notariusza kurii biskupiej a późniejszego dyrektora archiwum ks. prof. Henryka Misztala ${ }^{6}$. Tak więc w 1716 j.a. akt osobowych księży znajdują się 572 fotografie. We wspomnianych aktach studentów i absolwentów Kolegium Teologicznego Archidiecezji Lubelskiej odna-

\footnotetext{
${ }^{6}$ Wywiad z ks. Franciszkiem Przytułą z 23 lipca 2021 r.
} 
leziono 1178 fotografii. W aktach parafialnych, w 582 jednostkach, znajduje się jedynie 47 zdjęć.

Tak więc ogółem zbiór fotografii w Archiwum Archidiecezjalnym Lubelskim liczy 10989 fotografii. Dane te mają charakter szacunkowy z uwagi na możliwość omyłki, choć wydaje się, że będąc efektem szczegółowej kwerendy, odpowiadają dość wiernie stanowi faktycznemu.

\section{Stan opracowania i warunki przechowywania zbiorów fotograficznych}

Zbiory fotograficzne zgromadzone w Archiwum Archidiecezjalnym Lubelskim nie zostały jeszcze w pełni uporządkowane ani opracowane, lecz są na etapie porządkowania archiwalnego. Utrzymywane są w tematycznym bądź geograficznym porządku akcesji. Nie mają właściwego inwentarza, jednak na potrzeby wewnętrzne (dla orientacji pracowników) zostały sporządzone odpowiednie spisy robocze, obejmujące wspomniane albumy, teczki, koperty, pudła archiwizacyjne oraz kroniki.

Albumy, teczki i koperty ponumerowano i nadano im tytuły, o ile takich nie miały. W przypadku kronik i niektórych pudeł archiwizacyjnych brak jest numeracji, jednak są na nich nadane im tytuły. Warto zauważyć, że część pudeł archiwizacyjnych została oznaczona sygnaturami według powstającego inwentarza, obejmującego niemal już uporządkowany zbiór akt z lat 1944-19827. Niektóre albumy i pudła archiwizacyjne mają pełne opisy archiwalne, inne tylko tytuły, niekiedy także daty. W przypadku akt personalnych i parafialnych, które mają swoje własne sygnatury i pełne opisy archiwalne, fotografie w nich zgromadzone są paginowane w sposób ciągły wraz z pozostałą zawartością jednostek.

Należy dodać, że w Archiwum Archidiecezjalnym Lubelskim przyjęta została jako punkt odniesienia i cenna podpowiedź - skądinąd nieobowiązująca formalnie w instytucjach kościelnych - decyzja Naczelnego Dyrektora Archiwów Państwowych z 2006 r., dotycząca metodyki opracowywania zasobów fotograficznych ${ }^{8}$. W konsekwencji planowane jest tematyczne uporządkowanie archiwalnego zbioru fotograficznego. Każdy z tematów będzie odpowiadał jednostce inwentarzowej. Na opis tematu będzie składać się z sygnatura tematu, tytuł tematu, krótki opis tematu, miejsce zarejestrowanego wydarzenia, daty skrajne wydarzenia i liczba obrazów, tj. fotografii w temacie. Pojedyncze fotografie występujące w temacie będą miały w opisie podane personalia osób na obrazie wraz z ewentualnie innymi jeszcze danymi ich dotyczącymi, nazwy obiektów znajdujących się na fotografii, opisy szczegółowe, datę wykonania fotografii oraz nazwę zakładu fotograficznego lub ewentualnie autora fotografii. Sygnatury nadawane tematycznym jednostkom inwentarzowym będą przydzielane w ten sposób, że o ile temat obejmować będzie wiele fotografii, to każda z nich otrzyma osobny

${ }^{7}$ AAL, sygn. Dz III 330, Zbiór fotografii XIX-XX wiek; AAL, sygn. Dz III 331, Zbiór fotografii XIX-XX wiek.

${ }^{8}$ Wskazówki metodyczne dotyczace zasad opracowania fotografii w archiwach państwowych, https://www.archiwa.gov.pl/images/docs/akty_normatywne/Dec_8_2006.pdf (dostęp: 24.07.2021). 
numer. Sygnatury zostaną zapisane zarówno na rewersie fotografii, jak i na jej materialnym zabezpieczeniu.

Zbiorom fotograficznym w Archiwum Archidiecezjalnym Lubelskim, tak jak całemu przechowywanemu w nim zasobowi, zostały zapewnione właściwe warunki w zakresie temperatury i wilgotności powietrza. W pomieszczeniach zamontowano klimatyzację i odpowiedni system wentylacji, utrzymujący dopuszczalny poziom dobowych wahań wilgotności. Materiały przechowywane są na półkach archiwalnych, na metalowych regałach jezdnych. Całość zbioru fotograficznego jest zabezpieczona. Albumy zostały złożone w pudłach ochronnych. Teczki, które nie wymagają dodatkowych pudeł ochronnych, dzielą się na standardowe i dedykowane, tj. wykonane w pracowni konserwatorskiej miejscowego archiwum na potrzeby ochrony konkretnych fotografii z racji ich gabarytów (13 sztuk). Koperty z fotografiami po części zostały złożone w pudłach ochronnych, po części zabezpieczone teczkami ochronnymi. Wszystkie akta personalne i parafialne są przechowywane w pudłach ochronnych. Materiały użyte do opakowania zdjęć nie zostały jednak zweryfikowane pod kątem atestu PAT (Photographic Activity Test), określającego stopień reakcji ze srebrem znajdującym się w warstwie obrazu fotografii.

Zgromadzonych fotografii w zasadzie nie poddano jak dotąd żadnym zabiegom konserwatorskim. Wyjątek stanowią wspomniane zdjęcia wielkogabarytowe $\mathrm{w}$ liczbie 13 sztuk $^{9}$. Zostały one oczyszczone przez gumkowanie. Zabieg ten został przeprowadzony przez pracowników komórki konserwatorskiej miejscowego archiwum.

\section{Digitalizacja fotografii}

Archiwum Archidiecezjalne Lubelskie nie podjęło dotychczas systematycznej akcji digitalizacji zbioru fotograficznego. Niemniej jednak ok. 500 zdjęć spośród prawie 11000 zyskało swoją kopię cyfrową. Stanowi to zaledwie niecałe 5\% zbioru.

Digitalizacja w archiwum ma charakter okazjonalny. Przeprowadzana jest w odniesieniu do konkretnych zdjęć, na które pojawia się zapotrzebowanie z racji organizowanych wystaw lub przygotowywanych publikacji. Oba rodzaje działalności podejmowane są w pewnym zakresie przez Archiwum Archidiecezjalne Lubelskie. W większym stopniu wiążą się one wszakże z inicjatywami podmiotów zewnętrznych. Przy okazji zamówień na usługę reprograficzną składanych przez użytkowników indywidualnych lub instytucjonalnych - w tym lubelskiej prasy kościelnej i wydawnictwa archidiecezjalnego - kopia zdigitalizowanych materiałów pozostaje $\mathrm{w}$ archiwum ${ }^{10}$. Warto dodać, że zdjęcia, które zyskały kopie

${ }^{9}$ Wśród nich znalazła się ciekawa fotografia przedstawiająca marszałka Józefa Piłsudskiego w otoczeniu duchowieństwa lubelskiego w czasie trwającej wojny z Rosją sowiecką - AAL, bez sygn., Teczka 24, Naczelnik Państwa Józef Piłsudski z JE Ks. Biskupem Marianem Leonem Fulmanem przed kościołem katedralnym w Lublinie w dniu 11 stycznia 1920 roku po uroczystym nabożeństwie.

${ }^{10}$ Przykładowo, w 2019 r. wykonano na prośbę Wydawnictwa Archidiecezji Lubelskiej „Gaudium” kopie zdjęć do albumu o bł. bp. Władysławie Goralu oraz do publikacji książkowej 
cyfrowe, nie zostały wyodrębnione ze zbioru fotograficznego, a ich kopie przechowywane są na specjalnie przeznaczonym do tego nośniku.

Wśród zachowanych fotografii w wersji cyfrowej przeważają zdjęcia osób, ale także nierzadko występują ważne wydarzenia kościelne, powiązane w jakiś sposób z czynnikami lokalnymi. Do tych ostatnich należą zatem fotografie z Soboru Watykańskiego II, obchody milenijne, koronacje obrazów, jak też zdjęcia z posług i obecności w Lublinie i diecezji kard. Karola Wojtyły i bp. Stefana Wyszyńskiego.

Digitalizacji fotografii dokonują archiwiści Archiwum Archidiecezjalnego Lubelskiego, a także pracownicy projektu „System e-Administracji Kościelnej”, realizowanego przez Archidiecezję Lubelską od 2018 r. w ramach Regionalnego Programu Operacyjnego Województwa Lubelskiego na lata 2014-2020 ${ }^{11}$. Ponadto digitalizację przeprowadzają - po uzyskaniu zezwolenia - podmioty zewnętrzne, co wiąże się $\mathrm{z}$ ich konkretnymi potrzebami w zakresie wyboru i opracowywania materiałów wystawienniczych i publikacyjnych, a także ze zindywidualizowanymi wymaganiami technicznymi.

W związku ze wspomnianą specyfiką wykonywanej digitalizacji fotografii nie zostały jak dotąd w achiwum przedsięwzięte żadne ustalenia właściwych parametrów skanowania. Niemniej jednak rozdzielczość wykonywanych kopii odpowiada minimalnym standardom $\mathrm{w}$ tym zakresie, wynoszącym z reguły 600 ppi.

Pomieszczenie do digitalizacji, z racji współdzielenia funkcji, nie jest właściwie przygotowane pod względem ograniczenia zewnętrznych źródeł światła, moż-

o cudzie lubelskim z 3 lipca 1949 r. Na wystawę zorganizowaną przez Katolickie Stowarzyszenie „Civitas Christiana” w parafii pw. św. Jozafata w Rejowcu z okazji 100-lecia jej erygowania udostępniono skany fotografii bp. Mariana Leona Fulmana. Do Muzeum Martyrologii „Pod Zegarem" w Lublinie przekazano na wystawę w wersji elektronicznej dokumenty i fotografie związane z bł. bp. W. Goralem. Lubelskiej redakcji „Gościa Niedzielnego” udostępniono zdjęcia abp. Bolesława Pylaka na potrzeby przygotowania artykułu w związku z jego śmiercią. W 2020 r. dla Oddziałowego Biura Badań Historycznych Instytutu Pamięci Narodowej w Lublinie Komisja Ścigania Zbrodni przeciwko Narodowi Polskiemu, na potrzeby publikacji albumu o dziejach Lubelszczyzny w okresie międzywojennym, wykonano reprodukcje materiałów fotograficznych dotyczących bp. M.L. Fulmana oraz alumnów lubelskiego seminarium z 1926 r.; AAL, bez sygn., Sprawozdanie z działalności Archiwum Archidiecezjalnego Lubelskiego za rok 2019, s. 6; AAL, bez sygn., Sprawozdanie z działalności Archiwum Archidiecezjalnego Lubelskiego za rok 2020, s. 3.

${ }^{11}$ „Celem projektu jest zakup i wdrożenie: infrastruktury informatycznej służącej zwiększeniu stopnia cyfryzacji administracji w tym aplikacji i systemów bazodanowych zapewniających poprawę efektywności zarządzania oraz uruchomienia komunikacji elektronicznej w Archidiecezji Lubelskiej; systemów teleinformatycznych zapewniających dostępność, integrację oraz cyfryzację nowych usług i poprawę funkcjonalności istniejących usług publicznych świadczonych drogą elektroniczną $\mathrm{w}$ zakresie m.in. e-administracji; systemów teleinformatycznych służących digitalizacji zasobów, tworzenie i rozwijanie repozytoriów cyfrowych z zapewnieniem warunków bezpiecznego przechowywania danych cyfrowych. (...) Zadania: 1. Zakup opracowań analitycznych warstwy programowej systemu; 2. Zakup oprogramowania (...); 3. Zakup sprzętu: (...) narzędzia do digitalizacji zbiorów historycznych; narzędzia do przetwarzania danych i dokumentów oraz tworzenia nowych form dokumentów; narzędzia do digitalizacji dokumentacji multimedialnej”, https://mapadotacji. gov.pl/projekty/779394 (dostęp: 24.07.2021). 
liwości całkowitego zaciemnienia, achromatycznego koloru ścian, podłogi i dodatkowego wyposażenia. Sprzętem używanym przez pracowników archiwum do digitalizacji jest skaner biurowy Sharp. Pracownicy wzmiankowanego projektu archidiecezjalnego posługują się profesjonalnym skanerem Zeutschel. Podmioty zewnętrzne wykorzystują w celu cyfryzacji zdjęć profesjonalny sprzęt fotograficzny.

\section{Udostępnianie zbioru}

Pomimo braku inwentarza zbioru zdjęć - co stanowi funkcję nieuporządkowania materiałów fotograficznych - Archiwum Archidiecezjalne Lubelskie podejmuje się udostępniania przechowywanych fotografii. Udostępnianie zbioru odbywa się w czytelni naukowej.

Odnośnie do niewielkiego zbioru kopii cyfrowych należy zauważyć, że archiwum nie ma własnego serwisu internetowego ani nie korzysta z serwisów utrzymywanych przez inne instytucje w celu udostępniania kopii cyfrowych. Zmianę w tym zakresie przyniesie finalizacja wspomnianego projektu „System e-Administracji Kościelnej”. Tymczasem z przechowywanych kopii cyfrowych można korzystać na komputerze stanowiącym wyposażenie czytelni naukowej. Kopie cyfrowe przechowywanych zdjęć zasadniczo przeznaczone są na potrzeby własne użytkownika zasobu archiwalnego. Ich wykorzystanie w publikacjach lub prezentacjach wymaga formalnej zgody i jest płatne zgodnie z ustalonym cennikiem usług archiwalnych ${ }^{12}$.

Oczywistą i najprostszą formą użytkowania zdjęć jest korzystanie z fotografii wchodzących w skład uporządkowanych jednostek archiwalnych, takich jak akta parafialne lub personalne, jakkolwiek te ostatnie stanowią zbiór zastrzeżony ${ }^{13}$. Osobną kwestię stanowi udostępnianie fotografii w ramach zgłoszonego przez użytkowników zasobu archiwalnego zapotrzebowania na zdjęcia o danej tematyce. Po uprzedniej kwerendzie sprawdzającej ich obecność, zgodnie z posiadanymi spisami roboczymi, ewentualnym opisem fotografii i wiedzą archiwistów, można bez przeszkód korzystać z przechowywanego zbioru. Problem stanowi natomiast znaczny odsetek fotografii najstarszych - z XIX i pierwszej połowy XX wieku, które pozostają anonimowe $\mathrm{z}$ uwagi na brak zaopatrzenia ich w opisy na właściwym etapie dziejów. Współcześnie rozpoznanie takich zdjęć jest bardzo trudne. Nie należy zatem wykluczać, że prośby o udostępnienie fotografii o danych postaciach lub wydarzeniach pozostają niezrealizowane tylko z wymienionych powodów.

\section{Exemplum - fotografie dotyczące bł. bp. Władysława Gorala}

Pośród licznych fotografii przechowywanych w Archiwum Archidiecezjalnym Lubelskim warto zwrócić uwagę na zdjęcia dotyczące postaci bł. bp. W. Go-

${ }^{12}$ Cennik uslug archiwalnych świadczonych w Archiwum Archidiecezjalnym Lubelskim, https:// archiwum.diecezja.lublin.pl/cennik.html (dostęp: 24.07.2021).

13 „Korzystanie z materiałów zastrzeżonych wymaga zgody Arcybiskupa Lubelskiego”, Regulamin Archiwum Archidiecezjalnego Lubelskiego § 1 p. 2, https://archiwum.diecezja.lublin.pl/ regulamin.html (dostęp: 24.07.2021). 
rala. Ich obecność i usytuowanie w zbiorach są przykładem efektu celowych działań w zakresie realizacji potrzeb i zadań wspólnoty kościelnej. Otóż w przeciwieństwie do innych teczek akt personalnych akta osobowe bp. Gorala pozostają materiałem specyficznym, jako że znalazły się wśród nich także materiały innej proweniencji, zgromadzone na potrzeby prowadzonego procesu beatyfikacyjnego. Akta osobowe biskupa zostały oznaczone w archiwum sygnaturą Rep $60 \mathrm{IIb}$ G57. Składa się na nie 6 osobnych teczek: nr 1 - Akta osobiste ks. Władysława Gorala; nr 2 - Akta zbierane do procesu beatyfikacyjnego; nr 3 - Fotografie; nr 4 - Fotokopie z dokumentów; nr 5 - Dokumenty różne; nr 6 - Listy. Tak więc fotografie bp. W. Gorala, w przeciwieństwie do innych fotografii znajdujących się $\mathrm{w}$ aktach personalnych przechowywanych w archiwum, zostały wydzielone w ramach jednostki archiwalnej, a ponadto ich proweniencja pozostaje mocno zróżnicowana. Wynika to z faktu prowadzenia szerokiej kwerendy archiwalnej, obejmującej także materiały fotograficzne przydatne lub wprost niezbędne do fachowego przeprowadzenia procesu beatyfikacyjnego. Rezultatem tych zabiegów było włączenie zgromadzonych fotografii do akt personalnych i osadzenie ich w tych aktach we wzmiankowany sposób ${ }^{14}$.

W aktach osobowych biskupa znajduje się łącznie 71 zdjęć. Przechowywane są w osobnych kopertach. Każde z nich zostało zaopatrzone w numer porządkowy od 1 do 71. Niektóre zdjęcia mają szczegółowy opis, inne tylko opis ogólny. Spośród omawianej grupy fotografii prawie połowa, bo aż 32 zdjęcia, zyskała kopie cyfrowe ${ }^{15}$.

Zdjęcia przechowywane $\mathrm{w}$ teczce $\mathrm{nr} 3 \mathrm{w}$ aktach personalnych nie są jedyną dokumentacją fotograficzną w Archiwum Archidiecezjalnym Lubelskim odnoszącą się bezpośrednio do bp. W. Gorala. Postaci tej dotyczą bowiem także niektóre albumy zdjęciowe. W roboczym spisie fotografii przechowywanych w archiwum oznaczone zostały numerami od 1 do $4 \mathrm{w}$ zbiorze albumów ${ }^{16}$. Albumy zawierają łącznie 96 fotografii.

14 J.R. Marczewski, Dokumentacja życia i świętości bp. Władysława Gorala (1898-1945) w zasobach Archiwum Archidiecezjalnego Lubelskiego, „Zeszyty Społeczne KIK”, 23 (2020) s. 85.

${ }^{15}$ „Część fotografii w teczce trzeciej ma charakter portretowy. Inne natomiast to zdjęcia okolicznościowe, wśród których znajdują się sceny związane $\mathrm{z}$ wizytami biskupa $\mathrm{w}$ takich miejscowościach, jak: Wojsławice, Pawłów, Czułczyce, Podgórze, Krasienin, Cyców, Rejowiec, Łukowa i Klesztów. Większość zdjęć pochodzi ze znanych lokalnych pracowni fotograficznych okresu międzywojennego. Zdjęcia portretowe zostały wykonane w Lublinie przez atelier «Sztuka» z siedzibą przy ul. Krakowskie Przedmieście 41, a także przez Ludwika Hartwiga w pracowni przy ul. Krakowskie Przedmieście 29, jak również przez jego syna Edwarda Hartwiga, właściciela atelier «Fotorys» z siedzibą przy ul. Narutowicza 19. Ten ostatni autor wykonał także fotografie na placu przed katedrą lubelską w dniu uroczystości konsekracji bpa Gorala. Natomiast zdjęcia z wizyt biskupa na Chełmszczyźnie wykonane zostały przez pracownię fotograficzną «Kupś» z siedzibą przy ul. Lubelskiej 75 w Chełmie. Warto dodać, że wśród zbioru fotografii znalazł się również sfotografowany projekt herbu biskupiego", Marczewski, Dokumentacja życia i świętości bp. Władysława Gorala, s. 88-89.

${ }^{16}$ „Album pierwszy, to album ofiarowany ks. Goralowi 27 czerwca 1938 roku z okazji jego imienin przez Zarząd Okręgowy Chrześcijańskich Związków Zawodowych w Lublinie. Ks. Goral był wówczas kapelanem związków i wiceprezesem zarządu. Wewnątrz albumu znajduje się jed- 
Bez wątpienia w całym zasobie archiwalnym można się jeszcze spodziewać dodatkowych fotografii związanych $\mathrm{z} \mathrm{bp}$. W. Goralem, przeoczonych w toku prac beatyfikacyjnych, a będących świadectwem jego różnorakiego zaangażowania kapłańskiego i osobistych kontaktów interpersonalnych. Przykładem pozostaje pojedyncza fotografia znajdująca się w aktach personalnych ks. Piotra GintowtaDziewałtowskiego, proboszcza parafii Kamionka w latach 1935-1940, przedstawiająca bp. W. Gorala wśród parafian kamionkowskich w czasie wizytacji kanonicznej odbywanej 23 października 1938 r. ${ }^{17}$

\section{Podsumowanie}

Podsumowując, należy stwierdzić, że materiały fotograficzne znajdujące się w Archiwum Archidiecezjalnym Lubelskim są stosunkowo liczne. Wynika to z zakresu chronologicznego dziejów, rozciągłości terytorialnej, skali organizacyjnej i liczebności personalnej lokalnego Kościoła. Równocześnie można zauważyć, że materiały te stanowiły część zasobu archiwalnego pozostającego do niedawna w obszarze mniejszego zainteresowania. Inicjatywy skutecznie podejmowane na tym polu zarówno przez instytucje świeckie, jak i kościelne domagają się uzupełnienia braków w postaci przeprowadzenia porządkowania archiwalnego, sporządzenia właściwego inwentarza, a w wypadkach koniecznych także konserwacji zbioru. Wydaje się, że działania te winny być także nastawione na pełną digitalizację zbioru fotograficznego, której wymaga współczesny kontekst cywilizacyjny.

nak tylko jedna fotografia czarno-biała, przedstawiająca ks. Gorala w otoczeniu zarządu związków. Album drugi dokumentuje wizytację pasterską bpa Gorala, odbytą wiosną 1939 roku w parafii Wojsławice. Album zawiera 30 małoformatowych fotografii przedstawiających przebieg wizytacji pasterskiej: powitanie biskupa w specjalnie przygotowanej bramie, banderię konną, spotkania z kapłanami i wiernymi, a także z lokalną społecznością żydowską. Album trzeci został ofiarowany bpowi Goralowi przez ks. Zygmunta Grzegorzewskiego, proboszcza w Sawinie, z racji wizytacji odbytej w dniach od 27 do 29 maja 1939 roku. Album zawiera 37 małoformatowych fotografii przedstawiających przebieg wizytacji pasterskiej, w tym przybycie biskupa bryczką, procesjonalne wprowadzenie do kościoła, przemówienie na zewnątrz świątyni ze specjalnie przygotowanej ambony do licznie zgromadzonych wiernych, zaś ostatnie zdjęcie przedstawia biskupa w otoczeniu kapłanów i świeckich mężczyzn różnych godności, niektórzy z nich noszą mundury wojskowe. Zdjęcia nie zostały szczegółowo opisane przez ofiarodawcę. Album czwarty dokumentuje wizytację pasterską bpa Gorala w dniach od 9 do 11 maja 1939 roku w parafii Łukowa. Jest darem ówczesnego proboszcza ks. Ludwika Liwerskiego. Album zawiera fotografie małoformatowe, wszystkie zostały podpisane. Prezentuje przebieg wizytacji, której częścią było poświęcenia domu Akcji Katolickiej w Łukowej”, Marczewski, Dokumentacja życia i świętości bp. Władysława Gorala, s. 91-92.

${ }^{17}$ AAL, sygn. Rep 60 IIb G47, Akta osobowe ks. Piotra Gintowta-Dziewałtowskiego. 


\section{REFERENCES / BIBLIOGRAFIA}

\section{Źródla}

Archiwum Archidiecezjalne Lubelskie (AAL)

bez sygn., Sprawozdanie z działalności Archiwum Archidiecezjalnego Lubelskiego za rok 2019.

bez sygn., Sprawozdanie z działalności Archiwum Archidiecezjalnego Lubelskiego za rok 2020.

bez sygn., Teczka 24, Naczelnik Państwa Józef Piłsudski z JE Ks. Biskupem Marianem Leonem Fulmanem przed kościołem katedralnym w Lublinie w dniu 11 stycznia 1920 roku po uroczystym nabożeństwie.

sygn. Dz III 330, Zbiór fotografii XIX-XX wiek.

sygn. Dz III 331, Zbiór fotografii XIX-XX wiek.

sygn. Rep 60 IIb G47, Akta osobowe ks. Piotra Gintowta-Dziewałtowskiego.

sygn. Rep 60 IIb G57, Akta osobowe ks. bp. Władysława Gorala.

\section{Opracowania}

Marczewski Jarosław Roman, Archiwum Archidiecezjalne Lubelskie. Dzieje, zasób, inwentarz, Lublin 2015.

Marczewski Jarosław Roman, Dokumentacja życia i świętości bp. Władysława Gorala (1898-1945) w zasobach Archiwum Archidiecezjalnego Lubelskiego, „Zeszyty Społeczne KIK”, 23 (2020) s. 83-92.

\section{Netografia}

Cennik ustug archiwalnych świadczonych w Archiwum Archidiecezjalnym Lubelskim, https://archiwum.diecezja.lublin.pl/cennik.html (dostęp: 24.07.2021).

Regulamin Archiwum Archidiecezjalnego Lubelskiego, https://archiwum.diecezja.lublin. pl/regulamin.html (dostęp: 24.07.2021).

Wskazówki metodyczne dotyczace zasad opracowania fotografii $w$ archiwach państwowych, https://www.archiwa.gov.pl/images/docs/akty_normatywne/Dec_8_2006.pdf (dostęp: 24.07.2021).

https://analytics.google.com (dostęp: 24.07.2021).

https://mapadotacji.gov.pl/projekty/779394 (dostęp: 24.07.2021).

\section{Wywiady}

Wywiad z ks. Franciszkiem Przytułą z 23 lipca 2021 r. 


\title{
PHOTOGRAPHIC COLLECTION IN THE LUBLIN ARCHDIOCESAN ARCHIVES
}

\begin{abstract}
The Lublin Archdiocesan Archives store a collection of approximately 11,000 photographs from the 19th, 20th and 21st centuries. This collection still has to be put in order to respect fully all archival standards. It does not have a proper inventory yet. For internal purposes, only simple lists of photographs have been created. The collection is divided, according to the order of accession, into albums, chronicles, folders, envelopes and archival boxes. A significant part of the photographs finds its place in the personal and parish files. The photographs are digitalized to a very small extent. Their digital copies are prepared in an unsystematic way, mainly for the ad hoc purposes of current exhibitions and planned publications. Nevertheless, the photographic collection attracts increasing interest and is made available to public. The collection includes interesting objects, such as an extensive group of photos gathered for the purpose of beatification processes.
\end{abstract}

Keywords: photographs; digitalization; the Lublin Archdiocesan Archives; the Archdiocese of Lublin 